\title{
REPORT ON GREEN FROG \\ (EUPHLYCTIS HEXADACTYLUS) \\ FROM VENGAIVASAL LAKE \\ (TAMILNADU, INDIA)
}

Ravichandran RAMANIBAI * and Sivalingam GOVINDAN **

* University of Madras, Department of Zoology, Unit of Aquatic Biodiversity, Guindy Campus Chennai 25, Tamil Nadu, India, rramani8@hotmail.com

** University of Madras, Department of Zoology, Unit of Aquatic Biodiversity, Guindy Campus Chennai 25, Tamil Nadu, India, s.govindan88@gmail.com

DOI: 10.1515/trser-2015-0064

KEYWORDS: Anurans, Euphlyctis hexadactylus, Vengaivasal Lake, India.

\begin{abstract}
Through the Visual Encounter Survey only one species of green frog (Euphlyctis hexadactylus) was encountered. As we lack previous data we cannot comment on the decline of the species. Frogs, known for specific habitats, are under threats if such habitats are lost. The physico-chemical parameters estimated along with the anuran survey reported that the quality of the lake is not congenial to support the tadpoles of the frogs. The adults can move away from water and survive on land. The habitat, as well as the surrounding wetland, plays a vital role to support a good quantum of anurans.

RESUMEN: Informe sobre la rana verde (Euphlyctis hexadactylus) del lago Vengaivasal (Tamilnadu, India).

Tras realizar un muestreo visual, se encontró solo una especie de rana (Euphlyctis hexadactylus). En virtud de que no existen estudios previos, no es posible saber si los números poblacionales de esta especie están declinando. Las ranas se encuentran relacionadas con hábitats muy particulares y por lo tanto éstas se verán amenazadas si dichos hábitats se perdieran. Los parámetros fisicoquímicos que fueron tomados en el lago a la par del muestreo visual, indican que la calidad del agua no es propicia para la sobrevivencia de los ajolotes de esta especie, sin embargo los adultos si pueden moverse a otros cuerpos de agua. La integridad de los estos hábitats y de sus alrededores juega un papel preponderante para sostener una cantidad razonable de anuros.
\end{abstract}

REZUMAT: Raport privind broasca verde (Euphlyctis hexadactylus) din Lacul Vengaivasal (Tamilnadu, India).

$\mathrm{Cu}$ ajutorul studiului Visual Encounter doar o specie de broască verde (Euphlyctis hexadactylus) a fost semnalată. Datorită absenței informațiilor din trecut nu putem comenta sau interpreta scăderea numărului de invidivizi sau fragmentarea habitatelor populate. Broaștele sunt recunoscute ca având habitate specifice, iar sub stres acestea pot fi degradate. Calitatea lacului nu este propice pentru existența mormolocilor de broască, fapt ce reiese din parametrii fizico-chimici identificați în acest studiu. Adulții se pot îndepărta de apă și trăi pe sol. Atât habitatul cât și zonele umede adiacente joacă un rol extrem de important în existența anurelor. 


\section{INTRODUCTION}

In India, so far 347 species of amphibians were reported (Dines et al., 2012) out of which 77 species were reported from a variety of fresh water habitats of Chennai (Dinesh et al., 2012). Over 200 amphibian species have been reported to become extinct in the recent past, which gave an alarming signal to create awareness towards this.

Our regional problem is how to control mosquitoes. The Aedes mosquitoes spread Dengue and Chickenkunia to humans. Mosquitoes create a tremendous health hazard and need an indicator species to advocate and control their prevalence (Blaustein and Wake, 1990; Vitt et al., 1990; Wyman, 1990). Frogs are good predators and consume a large quantity of mosquitoes at their larval stage, thereby serving as a good biocontrol agent to control mosquito populations. Research has been initiated through integrated biocontrol methods which use frogs as a promising agent to control mosquito menace during early stages.

The main reason for the major decline in amphibian biodiversity is their sensitivity to a wide variety of environmental perturbations which has led them to be considered as bioindicators of ecosystem health (Wake and Vredenburg, 2008), and often cited as the "ecological canaries in the coal mine" (Pechmann and Wilbur, 1994). Urbanization is one of the threats to anurans apart from land cover changes and loss of habitats (Stuart et al., 2004).

\section{MATERIAL AND METHODS}

E. hexadactylus is a large aquatic anuran found in all kinds of water bodies, mostly reported in brackish water. During 2014, from February 1st week onwards, the Visual Encounter Survey was carried out. Instead of collecting voucher samples, pictures were captured and kept as reference for identification of anurans. Collected at four locations and fixed based on our preliminary surveys (Fig. 1a, b).

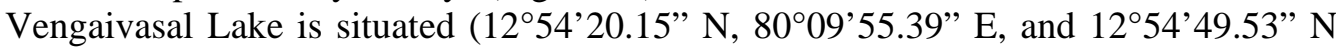
$80^{\circ} 09^{\prime} 55.64$ ” E) in Kanchipuram District of Tamilnadu (Fig. 1). Many small and medium size agricultural fields benefit out of this lake (Fig. 2). Vengaivasal Village housed nearly 10,000 residents living across its four square kilometres spread area around the lake.

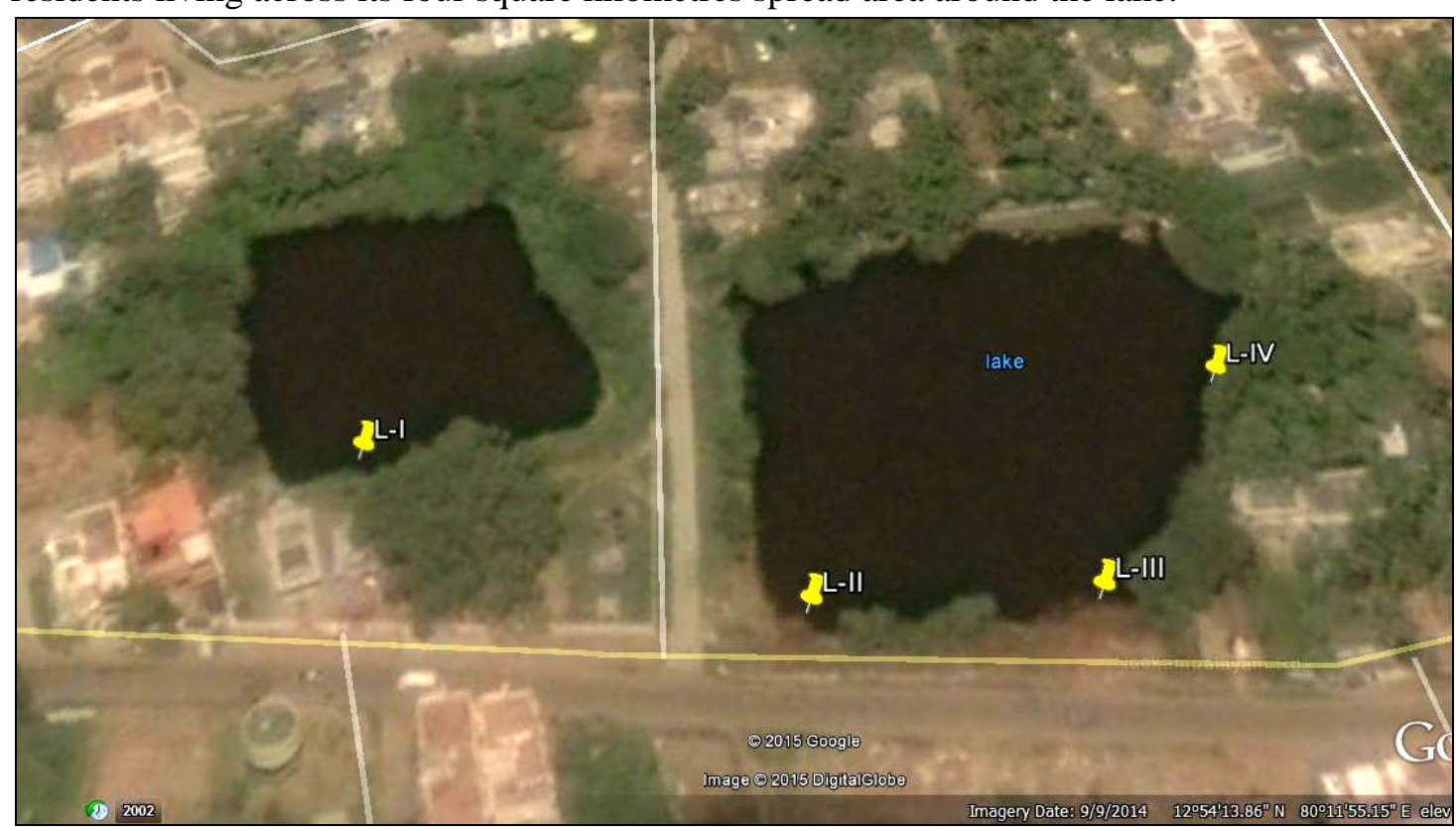

Figure 1a: Vengaivasal study area. 
Visual Encounter Survey (VES) is a simple method for identification. The Indian Pond Frog Euphlyctis hexadactylus is predominantly an aquatic species. Nearly 24 frogs basking on the leaves were recorded. It was quite unusual to notice this behaviour of frogs. The frogs were fully out on land exposing their entire body. Some frogs were floating still on the surface of the water. This floating surface basking and half or two-thirds of the body in water is commonly seen in amphibians. The frogs basking on land during the midday sun was an unusual sight. So the observation was continued from February 1st 2014 onwards. It is a regular phenomenon that pond frogs come out of the water bodies during night time and rest on land. Frogs are thought to be sensitive to acidic precipitation because they respire through their skin. It helps to sight and locate any individual current in the proposed study site. The frogs responded to the camera flash, and immediately hopped away to avoid the flash. Within that fraction of time available we captured their pictures. More green frogs were observed during the late evenings of the monsoon months, and with the help of photographs identified up to species level.

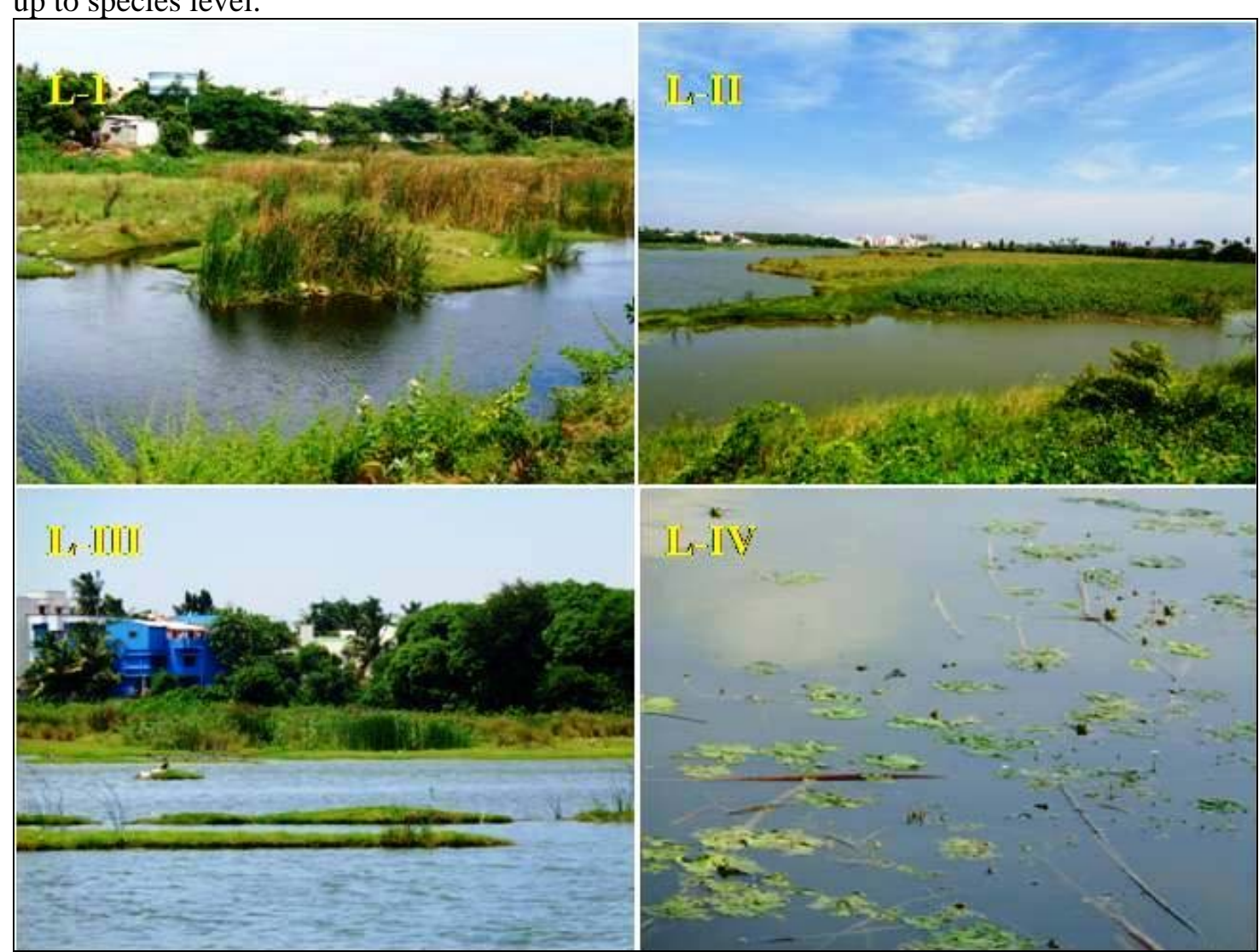

Figure 1b: Vengaivasal study area.

Experimental analysis. Physico-chemical parameters of these samples were determined by using standard procedures (APHA, 1992). The $\mathrm{pH}$ is determined by Eli co, digital $\mathrm{pH}$ meter which gives direct values of $\mathrm{pH}$. Temperature: A mercury filled centigrade thermometer calibrated from 0 to $100^{\circ} \mathrm{C}$ is used for temperature measurements.

Carbonate and bicarbonate: The water sample is determined by titrating it against standard acid solution using indicators like phenolphthalein and methyl orange. 
Total dissolved solids: $100 \mathrm{ml}$ of water sample is filtered through ordinary filter paper and water is collected in the evaporating dish of known weight. Further, it is heated and the water is totally evaporated. Whatever dissolved solid matter is present gets accumulated at the bottom of the evaporating dish. The evaporating dish is cooled and weighed. By weight, difference methods of the total dissolved solids are determined.

\section{RESULTS AND DISCUSSION Description of Green Frog}

The body of the frog was elongated with a maximum jumping length of about $70 \mathrm{~cm}$. The dorsal side was greenish and with a yellow straight line in the centre, and the ventral side was pale yellow in colour. The limbs are long and slender whereas the fore limbs are comparatively small. The prominent black eyes protrude on the front of the head (Fig. 3). Based on the key given by Seshadri et al. (2012), we identified mature individuals with the characters of the Green frog (Euphlyctis hexadactylus).

The size of the male frogs ranged between 85 and $90 \mathrm{~mm}$ and females from 125 and $130 \mathrm{~mm}$. They were found actively swimming on the surface of the lake and at times inside the aquatic vegetation too. It has a flat broad snout pointed towards the end and almost looks like an inverted "V." The dorsal side is a light green and light yellow mixture of colour and the ventral side is a pure lemon yellow colour. The eyes were prominent, projected and black in colour. The camthus rostalis and tympanum are distinct. The toes are fully webbed; the first finger is longer than the second one. Almost all of them are matured and bulky. They feed mostly on the insects and tadpoles. During monsoon season they breed and laid nearly 2000 eggs with in a diameter of one $\mathrm{mm}$.

Vegetation of an area plays a vital role for supporting the survival strategy of any particular animal and is the main composition of a habitat. The vegetation of the study area has certain impacts on the amphibian populations. Many frogs are habitat specific. They will be under threat if their habitats come under deterioration. Habitats are one of the most important factors for amphibian existence, freshwater ecosystem along with thick tropical vegetation offer excellent habitats for anurans (Dey, 2004). Frogs specially prefer marshy areas. Indian five fingered frog was the most common in all types of wetlands. The amphibian abundance and diversity fluctuate directly with changes in the composition and amount of microhabitats. They may signal environmental stress earlier than most other organisms (Gardner et al., 2007). Habitat loss and modification is considered to be one of the reasons for amphibian declines (Gardner et al., 2007). E. hexadactylus was found only in water or in water logged cultivation areas (Seshadri et al., 2012). E. hexadactylus is commonly being hunted for consumption of frog legs in the local market.

Even though the species documented during this study are common and widely distributed across the peninsular India, many could be threatened and may face population decline due to uncontrolled hunting activities and increased urbanization which could negatively affect their diversity. 


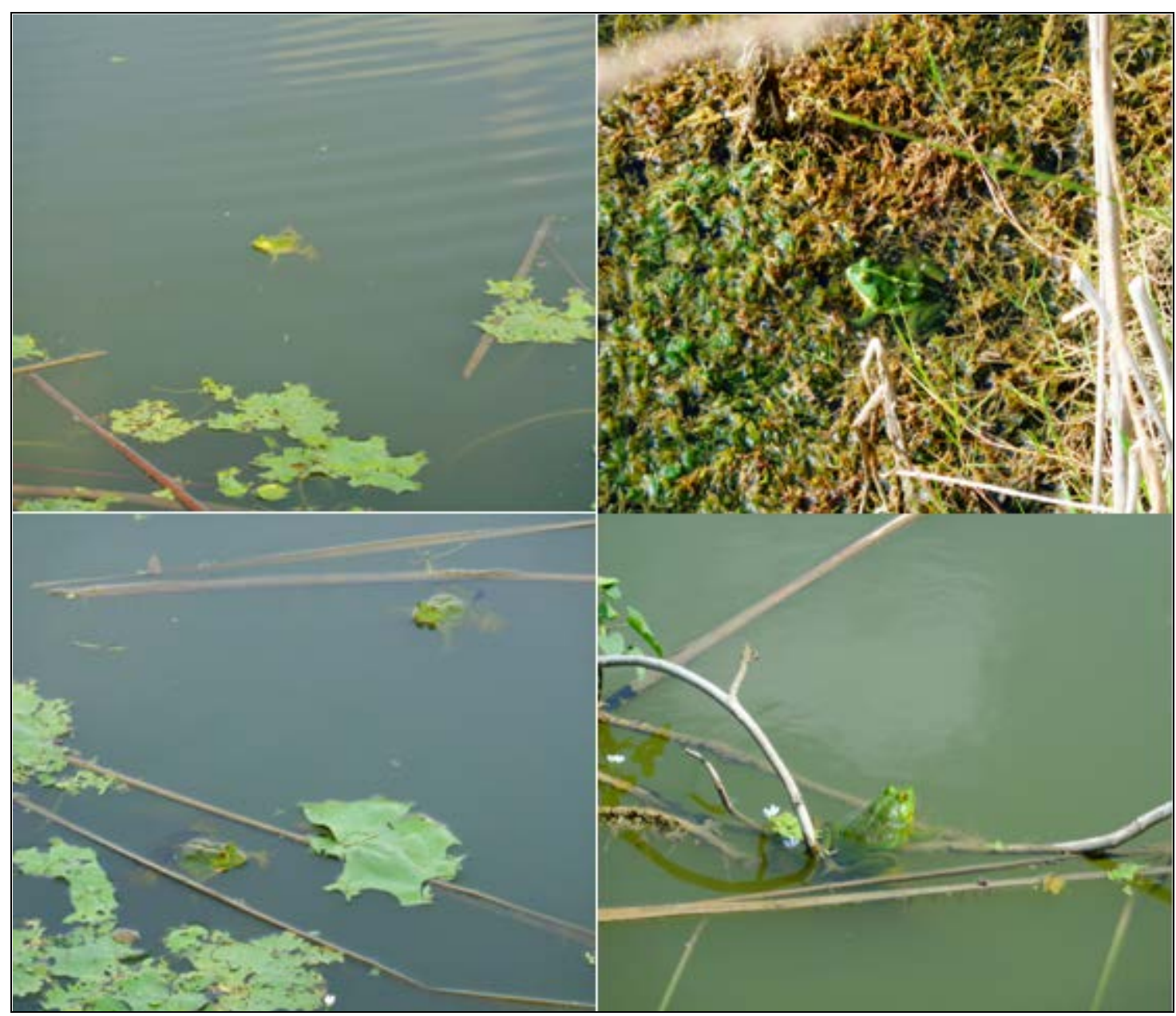

Figure 3: Euphlyctis hexadactylus in Vengaivasal Lake area.

According to the IUCN Red list, the current status of frogs come under the Least Concern. The only known herbivore frog exhibited a diet preference for plants. It was noted from the local residents that these frogs are caught for food. Habitat destruction and other climatic changes are considered to be the main reason for the decrease of amphibian population (Gardner et al., 2007). In India, due to the rapid urbanization and industrialization the amphibians decline occurs quickly (Padhye et al., 2002). A total of 16 species had been reported from Bangalore city (Karthikeyan, 1999). In Pune 31 species have been reported (Padhye et al., 2002).

It is estimated that freshwater wetlands support $20 \%$ of the range of biodiversity in India (Deepa and Ramachandra, 1999). Freshwater ecosystems are the most endangered ecosystems in the world. Biodiversity decline occurs far greater in fresh water habitats than in the most ecosystems (Sala et al., 2000; Dudgeon et al., 2006). The threats to global freshwater biodiversity can be grouped under five interacting categories: exploitation, water pollution, flow modification, destruction or degradation of habitat and invasion by exotic species (Allan and Flecker, 1993; Jackson et al., 2001; Rahel, 2002; Postel and Carpenter, 1997). 
In the present study, a comparative analysis of physical and chemical characteristics of Vengaivasal Lake water along with four location sites selected were made during Feb 2014 Mar 2015 and based on physical characteristics like pH, temperature, carbonate, bicarbonate and total dissolved solids the water quality has been assessed (Fig. 4).

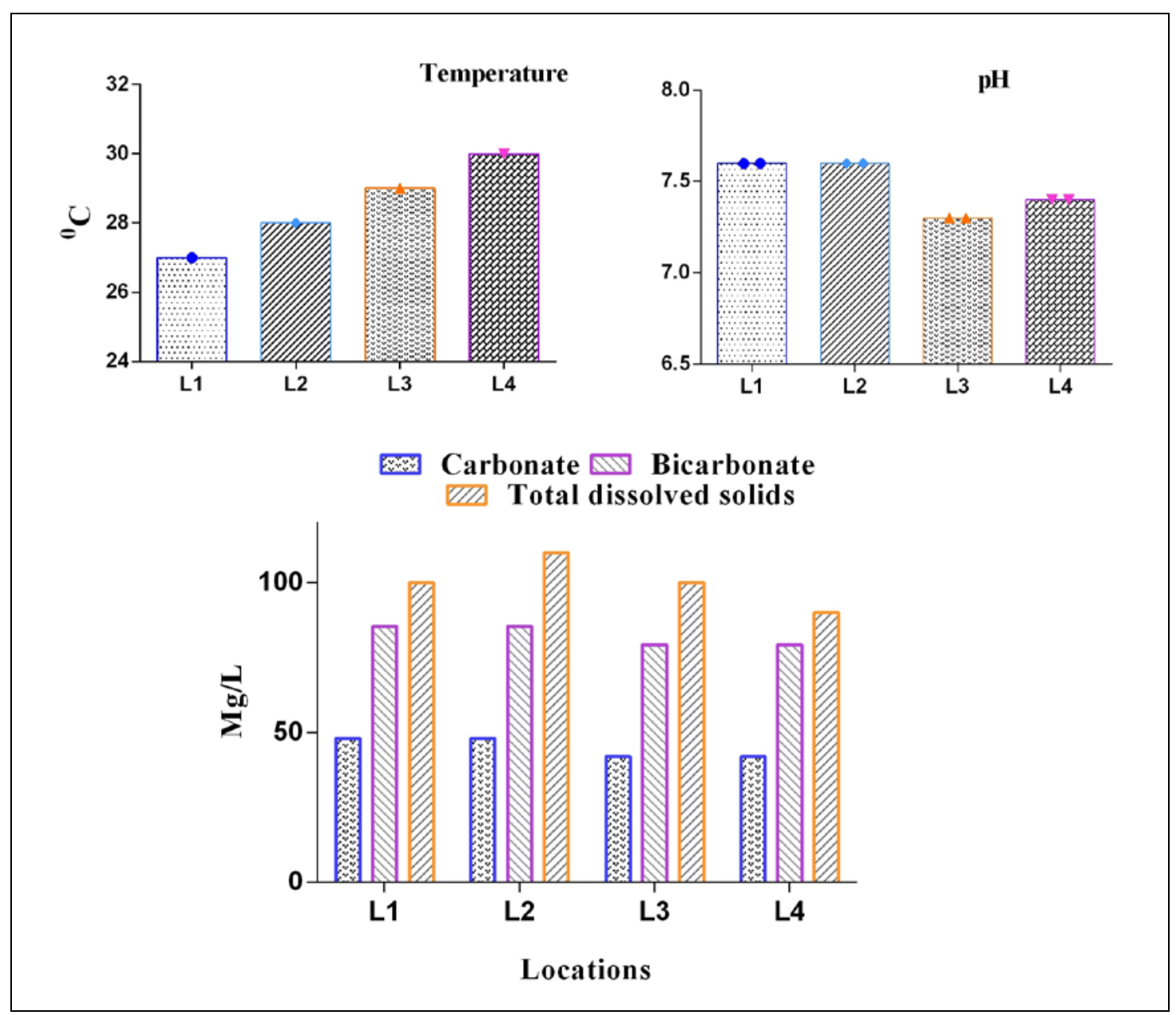

Figure 4: Physico-chemical parameters of Vengaivasal Lake.

\section{CONCLUSIONS}

Efforts to understand variations in richness and diversity in view of such disturbances need to be undertaken in the future for conserving anurans and the fragile wetland ecosystems in human dominated landscapes.

\section{ACKNOWLEDGEMENTS}

One of the authors (RR) acknowledge the funding support by DST (SERB) to carry out this work, Ref.: No SR/SO/AS-12/2012 dt:11.1.2013. 


\section{REFERENCES}

1. Allan J. D. and Flecker A. S., 1993 - Biodiversity conservation in running waters, BioScience, 43, 32-43.

2. APHA, 1992 - Standard Methods of Examination of Water and Waste Water, 18th edition, USA.

3. Blaustein A. R. and Wake D. B., 1990 - Declining amphibian populations: a global phenomenon, Trends in Ecology and Evolution, 5, 203-204.

4. Deepa R. S. and Ramachandra T. V., 1999 - Impact of Urbanization in the Interconnectivity of Wetlands, Paper presented at the National Symposium on Remote Sensing Applications for Natural Resources: Retrospective and Perspective (XIX-XXI, 1999), Indian Society of Remote Sensing, Bangalore.

5. Dey M., 2004 - Decline of Rana taipehensis population in southern Assam, Frog leg, Newsletter of the DAPTH South Asia, August, 09.

6. Dinesh K. P., Radhakrishnan C., Gururaja K. V., Deuti K and Bhatt G., 2012 - A Checklist of Amphibian of India with IUCN Red list Status, updated till September 2012, http://zsi.gov. in/checklist/Amphibia-final.pdf downloaded on 25 December 2012.

7. Dudgeon D., Arthington A. H., Gessner M. O., Kawabata Z. I., Knowler D. J., LE` Ve`Que C., Naiman R. J., Prieur-Richard A. H., Soto D., Stiassny M. L. J. and Sullivan C. A., 2006 Freshwater biodiversity: importance, threats, status and conservation challenges, Biological Reviews, 81, 163-182.

8. Gardner T. A., Barlow J. and Peres C. A., 2007 - Paradox, presumption and pitfalls in conservation biology: the importance of habitat change for amphibians and reptiles, Biology Conservation, 138, 166-179.

9. Jackson R. B., Carpenter S. R., Dahm C. N., Mcknight D. M., Naiman R. J., Postel S. L. and Running S. W., 2001 - Water in a changing world, Ecological Applications, 11, 1027-1045.

10. Jetz W. and Rahbek C., 2002 - Geographic range size and determinants of avian species richness, Science, 297, 1548-1551.

11. Karthikeyan S., 1999 - The Fauna of Bangalore, Bangalore: World Wide Fund for Nature India, 48.

12. Padhye A. D., Mahabaleshwarkar M. and Ghate H. V., 2002 - An overview of Amphibian fauna of Pune District with special reference to their status in and around Pune city, Zoo's Print Journal, 17, 4, 757-740.

13. Pechmann J. H. K. and Wilbur H. M., 1994 - Putting declining amphibian populations in perspective - natural fluctuations and human impacts, Herpetologica, 50, 65-84.

14. Postel S. and Carpenter S., 1997 - Freshwater Ecosystem Services, in Nature's Services, Gretchen Daily, Edit. Island Press, Washington D. C., 195.

15. Rahel F. J., 2002 - Homogenization of freshwater faunas, Annual Review of Ecology, Evolution and Systematics, 33, 291-315.

16. Sala O. E., Stuart Chaplin III F., Armestro J. J., Berlow E. and Bloomfield J., 2000 - Global biodiversity scenarios for the year 2100, Science, 287, 1770-1774.

17. Seshadri K. S., Vivekchandra A. and Guru Raj K. V., 2012 - Anurans from wetland of Puducherry, along the East Coast of India, Check List, 8, 1, 023-026.

18. Stuart S. N., Chanson J. S., Cox N. A., Yong B. E., Roadrigues A. S. L., Fischman D. L. and Waller R. W., 2004 - Status and trend of amphibian decline and extinction worldwide, Science, 306, 1783-1786.

19. Vitt L., Caldwell J. P., Wilbur H. M. and Smith D. C., 1990 - Amphibians as harbingers of decay, Bioscience Journal, 40, 418.

20. Wake D. B. and Vredenburg V. T., 2008 - Are we in the midst of the sixth mass extinction? A review from the world of amphibians, Proceedings of the National Academy of Sciences of the United States of America, 105, 11466-11473. 
21. Wyman R. L., 1990 - What's happening to the amphibians? Conservation Biology, 4, 350-352. 